\title{
Fungsi Pengawasan Asas Netralitas Terhadap ASN Di Daerah Istimewa Yogyakarta oleh Badan Pengawas Pemilu DIY
}

\author{
Muhammad Khaisar Ajiprasetyo ${ }^{1 *}$, Bagus Sarnawa ${ }^{2}$ \\ ${ }^{1,2}$ Program Studi Hukum, Fakultas Hukum, Universitas Muhammadiyah Yogyakarta, Indonesia \\ *Korespondensi: m.khaisar.2014@law.umy.ac.id
}

\section{Info Artikel}

Diajukan: 04-08-2020

Direview: 08-08-2020

Direvisi: $10-08-2020$

Diterima: 24-08-2020

DOI: $10.18196 / \mathrm{mls} . v 1 i 4.9196$

\begin{abstract}
Abstrak
Badan Penyelenggara Pemilu yakni KPU, Bawaslu, DKPP melakukan tugasnya masing-masing. Dalam hal pengawasan proses pemilu di Provinsi DIY dilaksanakan oleh Bawaslu DIY berdasarkan Undang-Undang No 7 Tahun 2017 tentang Pemilu, Bawaslu berwenang mengawasi dan memproses pelanggaran yang terjadi dalam pelaksanaan pemilu. Diantara hal yang diawasi oleh Bawaslu DIY adalah netralitas ASN. Maka, pengawasan terhadap kenetralan ASN sangat
\end{abstract} diperlukan guna memastikan bahwa ASN tidak terlibat dalam politik praktis yang dapat menimbulkan permasalahan birokrasi. Penelitian ini bertujuan untuk mengetahui peran Bawaslu DIY terhadap asas netralitas ASN di DIY. Apakah ASN di DIY sudah mentaati asas netralitasnya sebagai ASN atau belum. Metode penelitian yang digunakan adalah penelitian empiris. Penelitian ini dilaksanakan di kantor Bawaslu Provinsi DIY. Berdasarkan penelitian yang dilakukan, pelanggaran pemilu sebenarnya masih terjadi di wilayah hukum Provinsi DIY, namun dalam hal pelanggaran netralitas ASN masih dikategorikan minim. Dari data yang didapat, bahwa netralitas ASN harus dijaga karena posisi ASN yang strategis dalam pemerintahan, maka pengawasan terhadap ASN dilakukan oleh Bawaslu mulai dari upaya pencegahan, upaya penindakan, hingga proses pemberian sanksi kepada ASN yang melanggar. Bawaslu harus terus melaksanakan kewajiban sesuai regulasi dan mengupgrade SDM juga menambah fasilitas yang dapat menunjang kinerja pengawasan pemilu agar pelanggaranpelanggaran yang masih terjadi dapat ditekan jumlahnya.

Keyword: aparatur sipil negara, bawaslu, netralitas, pemilu, pengawasan

\section{Pendahuluan}

Pemilu diselenggarakan secara langsung, umum, bebas, rahasia, jujur dan adil guna menghasilkan pemerintahan negara berdasarkan Pancasila dan Undang-Undang Dasar 1945. Pemilihan umum merupakan bagian penting dalam Negara demokrasi yang menganut sistem perwakilan. ${ }^{1}$

Lembaga penyelenggaraan pemilu telah dibentuk yang secara khusus bertugas untuk mengadakan atau menyelenggarakan pemilu yakni Komisi Pemilihan Umum (KPU). Dibentuknya badan independen ini langsung berdasarkan Pasal-Pasal di UUD RI 1945 diantaranya Pasal 1 ayat (2) dan (3), Pasal 18 ayat (3), Pasal 19 ayat (1), Pasal 20, Pasal 22C ayat (1) dan (2), Pasal 22E, Pasal 24C ayat (1) Undang-undang Dasar

\footnotetext{
${ }^{1}$ Moh. Kusnardi dan Harmaily Ibrahim, Pengantar Hukum Tata Negara, Jakarta: Pusat Studi Hukum Tata Negara Fak. UI, 1983 hlm. 328
} 
Negara Republik Indonesia 1945 dan diatur lebih lanjut dengan peraturan perundangundangan dibawahnya.

KPU sebagai badan yang menyelenggarakan pemilu di Indonesia tentunya perlu diawasi oleh badan independen lainnya yang sejajar dengan kedudukan KPU guna menjaga netralitas dan kualitas pemilu yang menyangkut keberlangsungan tata kelola pemerintah dalam kurun waktu 5 tahun kedepan. Maka dibentuklah suatu badan pengawas yang bertugas mengawasi dan memonitoring setiap proses pelaksanaan pemilu yang dinamai Badan Pengawasan Pemilihan Umum Republik Indonesia (Bawaslu RI). Pengawasan Bawaslu terhadap penyelenggara pemilu dilakukan dengan upaya pencegahan dan penindakan pelanggaran, dimana pelanggaran dan penyelesaian sengketa pemilu bukan bertujuan sebagai langkah penindakan namun lebih kepada upaya pencegahan. Dalam Pasal 1 poin 16 Undang-undang Nomor 15 Tahun 2011 tentang Penyelenggara Pemilu, Bawaslu adalah lembaga penyelenggara pemilu yang bertugas mengawasi penyelenggaraan pemilihan umum di seluruh wilayah NKRI.

Ketidaknetralan dari Aparatur Sipil Negara (ASN) ini dapat dimungkinkan bisa memberi keuntungan bagi salah satu pihak tertentu. Diantara akibat ketidaknetralan ASN diantaranya yaitu tidak adilnya atau tidak setaranya perlakuan ASN dalam pelaksanaan birokrasi yang cenderung baik kepada pihak tertentu dan menyulitkan bagi pihak lainnya. Masalah yang diuraikan pada penelitian ini adalah pengawasan asas netralitas ASN yang dilakukan oleh Bawaslu DIY?

\section{Metode Penelitian}

Penelitian ini merupakan penelitian hukum empiris dengan menggunakan pendekatan yuridis empiris, yang merupakan penelitian dengan mengkaji fakta-fakta yang terjadi di instansi terkait dengan pengawasan Bawaslu DIY terhadap asas netralitas ASN di DIY. Dengan menggunakan studi kepustakaan dan studi lapangan, dieroleh data yang kemudian dianalisa menggunakan tenik kualitatif. Pengumpulan data dalam peneitina ini dengan menggunakan wawancaran dan angket pada informan terkait.

\section{Hasil dan Pembahasan}

Badan Pengawas Pemilu (Bawaslu) merupakan badan independen yang dibentuk dalam rangka mewujudkan penyelenggaraan pemilihan umum yang berintegritas dan berkredibilitas sesuai dengan asas langsung, umum, bebas, rahasia, jujur, dan adil (LUBERJURDIL). Selain daripada itu integritas pemilu dapat meningkatkan partisipasi masyarakat dalam penyelenggaraan pemerintahan dan mampu meredam aktivitas protes masa. $^{2}$

\footnotetext{
${ }^{2}$ Rahmatinnisa, “Mengapa Integritas Pemilu Penting?”, Jurnal Bawaslu, Vol. 3, No. 1, (2017), Hal. 6
} 


\subsection{Tahapan Pelaksanaan Pengawasan}

Bawaslu mengawasi kepatuhan semua pihak yang terkait dengan penyelenggaraan pesta demokrasi, yakni penyelenggaraan pemilihan presiden, pemilihan legislative, maupun pemilihan kepala daerah, termasuk mengawasi kepatuhan netralitas Aparatur Sipil Negara, netralitas anggota Tentara Nasional Indonesia, dan netralitas anggota Kepolisian RI. Dalam hal itu bawaslu mempunyai kewenangan menerbitkan rekomendasi kepada instansi yang berwenang menjatuhkan sanksi terhadap pihak yang melakukan pelanggaran. Alur Bawaslu DIY dalam mewujudkan pemilu yang berintegritas dan berkredibilitas, yakni: ${ }^{3}$

\subsubsection{Pra Tahapan Pemilihan Umum}

Sebelum dilaksanakannya Pemilu, Bawaslu DIY mempunyai strategi pencegahan (upaya preventif). Pencegahan ini bertujuan agar pelanggaran saat pemilu tidak terjadi. Bawaslu provinsi memiliki tugas pencegahan terhadap pelanggaran pemilu dan sengketa proses Pemilu telah diatur dalam Pasal 98 ayat 1 Undang-undang Nomor 7 tahun 2017 Tentang Pemilihan Umum. ${ }^{4}$ Pencegahan juga diutamakan sebelum tahapan pemilu berlangsung dengan melihat potensi pelanggaran yang dapat terjadi saat pemilu berlangsung. Bentuk pencegahan yang dilakukan oleh Bawaslu DIY adalah dengan Penyusunan Indeks Kerawanan Pemilu (IKP), mengidentifikasi dan memetakan Tempat Pemungutan Suara yang rawan terjadi pelanggaran, menerbitkan Surat Himbauan (peringatan dini), sosialisasi pengawasan pemilu, media campaign berbasis media sosial, Bawaslu DIY mengintensifkan pengawasan kampanye pasangan calon melalui media sosial, Desa Anti Politik Uang (DAPU), memantau dan mengevaluasi penyelenggaraan pemilu, berkoordinasi dengan instansi pemerintah terkait, dan meningkatkan partisipasi masyarakat dalam pengawasan pemilu.

Rencana strategis Bawaslu telah mengeluarkan Peraturan Bawaslu Nomor 13 Tahun 2012 Tentang Tata Cara Pengawasan Pemilu. Peraturan ini secara khusus mengatur tentang partisipasi masyarakat dalam pengawasan, yakni dalam Pasal 22 ketentuan tersebut menyebutkan bahwa partisipasi masyarakat dalam pengawasan pemilu bisa dilakukan 4 (empat) cara, yakni pemantauan, penyampaian laporan awal dan/atau informasi awal temuan dugaan pelanggaran, kajian, kampanye pengawasan, dan bentuk lainnya yang tidak melanggar peraturan dan perundang-undangan. ${ }^{5}$

\footnotetext{
${ }^{3}$ Bagus Sarwono, Bawaslu Badan Pengawas Pemilu Daerah Istimewa Yogyakarta, https://docplayer.info/138498682-Bawaslu-badan-pengawas-pemilu-daerah-istimewa-yogyakarta.html , diakses 20 November 2019 pukul 15.30 WIB

${ }^{4}$ Teguh Prasetyo, Pemilu Bermartabat, Depok: Rajawali Press, 2017, hlm 124-125

${ }^{5}$ Muhamad Jabar, Aji Ratna Kusuma, dan Adam Idris, "Strategi Pengawasan Bawaslu Pada Pemilihan Bupati/Walikota Serentak di Kalimantan Timur Tahun 2015", eJournal Administrative Reform 2018, Vol. 6, No. 1, hal 13
} 
Peraturan Bawaslu Nomor 13 Tahun 2012 Tentang Tata Cara Pengawasan Pemilu juga memberikan paduan kepada Bawaslu dalam rangka meningkatkan partisipasi masyarakat dalam pengawasan pemilu sebagai berikut: ${ }^{6}$

a. Mendorong secara aktif peran masyarakat untuk mengawasi pemilu;

b. Menyediakan informasi, sarana atau fasilitas yang memadai untuk memudahkan masyarakat mengakses informasi tentang pengawasan Pemilu; dan

c. Menyiapkan sarana atau fasilitas yang mudah bagi masyarakat untuk menyampaikan informasi, pengaduan dan atau laporan pelanggaran pemilu.

Beberapa upaya Bawaslu DIY yakni melakukan sosialisasi kepada masyarakat mengenai pentingnya berdemokrasi melalu Pemilu dan meningkatkan kesadaran bahwa demokrasi yang baik adalah demokrasi yang berintegritas. Selain melalui sosialisasi Bawaslu DIY juga membuat iklan layanan masyarakat tentang edukasi Pemilu di media televisi, radio, jejaring media online, dan juga melalui baliho-baliho dan pamflet dijalanan umum. ${ }^{7}$

\subsubsection{Saat Tahapan Pemilu}

Bentuk pengawasan yang dilakukan Bawaslu DIY saat tahapan pemilu antara lain pengawasan langsung/melekat, pengawasan layar, pengawasan sampling, pengawasan wawancara. Pengawasan Bawaslu DIY terhadap ASN sendiri difokuskan untuk mengurangi pelanggaran pemilu yang biasanya terjadi yakni; pidana pemilu, pelanggaran administrasi, pelanggaran etik, dan pelanggaran regulasi lain atau undangundang. ${ }^{8}$ Pengawasan dilakukan supaya pelanggaran tidak terjadi, namun apabila pelanggaran tetap terjadi maka harus diproses sesuai dengan peraturan perundangundangan yang berlaku. Pelanggaran pemilu tersebut bisa dijabarkan sebagai berikut:

1) Pelanggaran pidana pemilu

Tindak pidana pelanggaran dan/atau kejahatan terhadap ketentuan tindak pidana pemilu sebagaimana yang diatur dalam UU No. 8 Tahun 2012.

2) Pelanggaran administrasi pemilu

Berdasarkan Pasal 460 Undang-Undang Nomor 7 Tahun 2017 Pelanggaran yang meliputi tata cara, prosedur, dan mekanisme yang berkaitan dengan administrasi pelaksanaan pemilu dalam setiap tahapan pemilu di luar tindak pidana pemilu dan pelanggaran kode etik penyelenggaraan pemilu. Contoh dari pelanggaran administratif pemilu berdasarkan Peraturan Komisi Pemilihan Umum Nomor 4 Tahun 2017 tentang Kampanye Pemilihan Gubernur dan Wakil, Bupati dan Wakil Bupati dan/atau Walikota dan Wakil Walikota yakni pelanggaran atribut kampanye, proses pembentukan

\footnotetext{
${ }^{6}$ Ibid, hal 14

${ }^{7}$ Hasil wawancara dengan Bapak Rachmat Hidayat Sofyan, Kepala Sub Bagian Hukum, Humas, dan Antar Lembaga Bawaslu DIY pada hari Senin tanggal 25 November 2019 pukul 09.30

${ }^{8}$ Hasil wawancara dengan Ibu Sutrisnowati, anggota Bawaslu DIY pada hari Jum'at tanggal 20 September 2019 pukul 10.15
} 
penyelenggaraan pemilu yang tidak sesuai dengan prosedur, tidak membuat surat tanda terima pemberitahuan dan belum membuat surat ijin cuti bagi pasangan calon, penggunaan tempat ibadah/keagamaan untuk keperluan kampanye, dan menurut Pasal 1 angka 21 Peraturan Badan Pengawas Pemilihan Umum RI Nomor 12 Tahun 2017 pemasangan alat peraga kampanye yang difasilitasi KPU Provinsi/KPU Kabupaten yang didanai menggunakan dana APBD sera didukung oleh APBN.

3) Pelanggaran kode etik penyelenggara pemilu

Pelanggaran terhadap etika penyelenggara pemilu yang berpedoman pada sumpah dan/atau janji sebelum menjalankan tugas sebagai penyelenggara pemilu. ${ }^{9}$

4) Pelanggaran regulasi atau undang-undang

Pelanggaran yang berkenaan dengan segala regulasi partisipan pemilu, baik secara langsung maupun tidak langsung, disengaja maupun tidak disengaja, sendiri maupun bersama-sama, dimana tindakan tersebut telah diatur berdasarkan undang-undang yang berlaku. $^{10}$

\subsubsection{Pasca Tahapan Pemilu}

Strategi selanjutnya yang dilakukan Bawaslu DIY pasca tahapan Pemilu adalah melakukan penindakan. Penindakan merupakan serangkaian proses penanganan pelanggaran dan penanganan sengketa dengan Standar Operasional Prosedur yang telah ditetapkan. Pengaruh dari penindakan sendiri adalah untuk meminimalisir supaya pelanggaran serupa tidak terjadi kembali. Bentuk dari penindakan yang dilakukan Bawaslu DIY antara lain melak

Mekanisme penanganan pelanggaran pemilu yang dilakukan Bawaslu dibagi menjadi (2) dua, yakni aktif dan pasif. Pada penanganan secara aktif, Bawaslu secara mandiri menemukan bentuk pelanggaran pemilu yang dilakukan ASN. Sedangkan penanganan secara pasif, Bawaslu mendapatkan laporan dari pihak yang melaporkan kepada Bawaslu tentang dugaan terjadinya pelanggaran. Pasal 6 Undang-undang Nomor 14 Tahun 2017 tentang Penanganan Laporan Pelanggaran Pemilihan Gubernur dan Wakil Gubernur, Bupati dan Wakil Bupati, serta Walikota dan Wakil Walikota mengatur tentang laporan pelanggaran pemilihan tersebut dapat disampaikan oleh Warga Negara Indonesia (WNI) yang mempunyai hak pilih pada pemilihan setempat, pemantau pemilihan, dan/atau peserta pemilihan.

Laporan pelanggaran pemilihan disampaikan secara tertulis yang memuat paling sedikit mencakup nama dan alamat pelapor, pihak terlapor, waktu dan tempat kejadian perkara dan uraian kejadian. Bawaslu DIY sendiri membawahi 5 Bawaslu Kabupaten/Kota, 78 Panwaslu kecamatan, 438 Panwaslu Kelurahan/Desa, dan 11.781

\footnotetext{
${ }^{9}$ Ni'matul Huda dan M. Imam Nasef, Penataan Demokrasi \& Pemilu di Indonesia Pasca Reformasi, Jakarta: Kencana, 2017, hlm 161

${ }^{10}$ Hasil wawancara dengan Ibu Sulistiowati, anggota Bawaslu DIY, pada hari Jum'at tanggal 20 September 2019, pukul 10.00 WIB
} 
Pengawas TPS. Selama tahapan penyelenggaraan pemilu tahun 2019, Bawaslu DIY besera Bawaslu Kabupayen/Kota se-DIY telah menangangi penindakan pelanggaran yang tersebar di seluruh wilayah DIY. Berikut sebaran penindakan pelanggarannya:
a. Bawaslu Kab. Sleman: Temuan: 4 dan Laporan: 8
b. Bawaslu Kab. Bantul: Temuan: 13 dan Laporan: 3
c. Bawaslu Kab. Gunung Kidul: Temuan: 6 dan Laporan: 8
d. Bawaslu Kab. Kulonprogo: Temuan: 8 dan Laporan: 6
e. Bawaslu Kota Yogyakarta: Temuan: 8 dan Laporan: 7
f. Bawaslu DIY: Temuan: 1 dan Laporan: 6

Berdasarkan data sebaran penindakan pelanggaran diatas dapat diketahui terdapat 65 pelanggaran pemilu yang terdiri dari 24 pelanggaran administrasi, 29 pelanggaran pidana, 7 pelanggaran kode etik, 3 pelanggaran hukum lain, dan 2 dinyatakan bukan pelanggaran. Dari data tersebut juga Bawaslu Bantul paling banyak melakukan penindakan pelanggaran. Sementara Bawaslu DIY paling sedikit dalam melakukan penindakan dibandingkan dengan 5 Kabupaten/Kota lainnya. ${ }^{11}$

Berdasarkan rekapitulasi data diatas dapat dilihat bahwa terdapat 66 (enam puluh enam) pelanggaran pada pemilu pada Tahun 2019 yang ditangani oleh Bawaslu se-DIY. Pelanggaran tersebut terdiri atas 40 (empat puluh) temuan dan 26 (dua puluh enam) laporan. Dari total tersebut, sebanyaknya 54 (lima puluh empat) perkara diregister dan sebanyak 12 (perkara) tidak diregister. Alasan dari perkara yang tidak diregister adalah karena tidak terpenuhinya persyaratan formil maupun materiil dari temuan/laporan dugaan pelanggaran pemilu tersebut diatas.

Selama penyelenggaraan tahapan pemilu 2019, Bawaslu se-DIY menangangi 2(dua) temuan dugaan pelanggaran hukum lainnya, yang mana pelanggaran asas netralitas ASN termasuk dalam pelanggaran tersebut. 2 (dua) temuan dugaan pelanggaran tersebut berasal dari Yogyakarta dan Bantul. Adanya 2 temuan pelanggaran hukum lainnya tersebut oleh Bawaslu DIY, langakah Bawaslu DIY melakukan penindakan terhadap dugaan pelanggaran tersebut dengan kurun waktu paling lama 7 hari sejak diketahui/ditemukan pelanggaran. Kemudian, ASN yang diduga melanggar asas netralitas dipanggil oleh Bawaslu melalui panggilan langsung ke instansi terkait, kemudian ASN tersebut diharuskan memenuhi panggilan dari Bawaslu DIY untuk melakukan klarifikasi terhadap dugaan yang disangkakan, waktu penanganan tersebut yakni 7 hari, namun jika dirasa perlu adanya penambahan waktu maka bisa diperpanjangan selama 7 hari lagi, sehingga total waktu penanganannya maksimal 14 hari. Apabila setelah ASN melakukan klarifikasi dan dianggap memenuhi unsur pelanggaran asas netralitas ASN yang disangkakan, maka Bawaslu DIY

\footnotetext{
${ }^{11}$ Sumber: Divisi Penindakan Pelanggaran Bawaslu DIY
} 
merekomendasikan kepada Komisi Aparatur Sipil Negara (KASN) dengan melampirkan berkas untuk menindaklanjuti investigasi dari Bawaslu DIY tersebut.

Tindakan yang sama dilakukan oleh Bawaslu DIY, apabila ASN yang diduga melakukan pelanggaran tidak memenuhi panggilan dari Bawaslu DIY dalam kurun waktu tertentu maka ASN tersebut dinyatakan bersalah dan akan diproses oleh KASN (dijatuhi sanksi oleh KASN). ${ }^{12}$ Apabila kasus tersebut sudah diterima oleh KASN, tindakan selanjutnya yang dilakukan oleh KASN adalah melakukan kroscek apakah penggalaran tersebut dinyatakan melanggar asas netralitas ASN atau melanggar regulasi lainnya, kemudian KASN menetapkan sanksi yang sesuai dengan pelanggaran tersebut. Setelah ditetapkan sanksi oleh KASN, putusan tersebut diserahkan kepada PPK (Pejabat Pembina Kepegawaian) untuk melaksanakan sanksi terhadap ASN yang bersalah. Semua proses tersebut tetap berada dalam monitoring Bawaslu DIY. ${ }^{13}$

Berdasarkan aturan yang berlaku, penjatuhan sanksi dilakukan oleh pejabat atau instansi yang berwenang. Instansi yang berwenang yaitu Komisi Aparatur Sipil Negara yang tetap mengkoordinasikan kepada Pejabat Pembina Kepegawaian. Penjatuhan sanksi tersebut berdasarkan tingkat pelanggaran ASN, dimana ketika ASN melakukan pelanggaran kode etik maka ASN tersebut dikenakan sanksi moral maupun sanksi administrasi. Sedangkan menurut Peraturan Pemerintah Nomor 53 Tahun 2010 tentang Disiplin Pegawai Negeri Sipil jika ASN melakukan pelanggaran terkait disiplin Pegawai Negeri Sipil (PNS) maka akan dijatuhi hukuman disiplin PNS, yakni:

1. Tingkat hukuman disiplin terdiri dari :
a. Hukuman disiplin ringan;
b. Hukuman disiplin sedang; dan
c. Hukuman disiplin berat.

2. Jenis hukuman disiplin ringan sebagaimana dimaksud pada ayat (1) huruf a terdiri dari :
a. Teguran lisan;
b. Teguran tertulis; dan
c. Pernyataan tidak puas secara tertulis.

3. Jenis hukuman disiplin sedang sebagaimana dimaksud pada ayat (1) huruf b terdiri dari :
a. Penundaan kenaikan gaji berkala selama 1 (satu) tahun;
b. Penundaan kenaikan pangkat selama 1 (satu) tahun; dan

\footnotetext{
${ }^{12}$ Hasil wawancara dengan Bapak Rachmat Hidayat Sofyan, Kepala Sub Bagian Hukum, Humas, dan Antar Lembaga Bawaslu DIY pada hari Senin tanggal 25 November 2019 pukul 09.30

${ }^{13}$ Hasil wawancara dengan Bapak Rachmat Hidayat Sofyan, Kepala Sub Bagian Hukum, Humas, dan Antar Lembaga Bawaslu DIY pada hari Senin tanggal 25 November 2019 pukul 09.30
} 
c. Penurunan pangkat setingkat lebih rendah selama 1 (satu) tahun.

4. Jenis hukuman disiplin berat sebagaimana dimaksud pada ayat (1) huruf c terdiri dari:
a. Penurunan pangkat setingkat lebih rendah selama 3 (tiga) tahun;
b. Pemindahan dalam rangka penurunan jabatan setingkat lebih rendah;
c. Pembebasan dari jabatan;
d. Pemberhentian dengan hormat tidak atas permintaan sendiri sebagai PNS; dan
e. Pemberhentian tidak dengan hormat sebagai PNS.

Mengenai pengawasan dan penanganan pelanggaran asas netralitas ASN selain bekerjasama dengan KASN, Bawaslu DIY juga berkerja sama dengan KPU DIY dan KPID DIY (Komisi Penyiaran Indonesia Daerah) dalam bentuk MoU (Memorandum of Understanding)/perjanjian kerjasama. Pada gelaran Pilkada 2018 dan Pemilu serentak 2019 dalam rangka menjaga netralitas ASN, KASN melakukan kerjasama dengan Kementerian Dalam Negeri dan Kementerian Aparatur Negara dan Reformasi Birokrasi. Ketiga lembaga tersebut mengeluarkan Surat Edaran sebagai langkah preventif yang ditujukan kepada seluruh instansi, baik di pusat maupun di daerah, yang secara general substansial merupakan petunjuk dan pengingat bahwasanya ASN harus bersikap netral. ${ }^{14}$ Bagus Sarnowo Ketua Bawaslu DIY, mengatakan hal terserbut dilakukan karena manyadari bahwasanya tidak semua urusan kepemiluan menjadi domain satu lembaga saja, namun juga domain lembaga lain. Sehingga kolaborasi tersebut sangat dibutuhkan demi mewujudkan Pemilu yang berintegritas. ${ }^{15}$

\subsection{Kendala Pelaksanaan Pengawasan}

Pada saat penyelenggaraan pemilu 2019 di DIY, Bawaslu DIY telah menjalankan amanatnya sebagai lembaga independen dalam menjalankan fungsi kepengawasannya. Hal tersebut juga didukung dengan adanya koordinasi yang baik antara penyelenggara dan pengawas serta pihak-pihak yang terlibat dalam pemilu. Pemilu 2019 di DIY juga sudah diselenggarakan dengan baik. Namun Bawaslu DIY memiliki beberapa hambatan atau kendala dalam menegakkan asas netralitas ASN dalam penyelenggaraan pemilu.

\subsubsection{Kendala dari segi regulasi}

Keterlibatan ASN dalam pelaksanaan kampanye salah satu pasangan calon maupun dalam mendukung salah satu pasangan calon tidak diatur dalam UU Pemilu maupun UU tentang ASN, yang diatur dalam UU Pemilu hanyalah pejabat ASN dan pelibatan ASN yang dilakukan oleh tim kampanye atau pelaksana kampanye, sehingga jika ada ASN yang terlibat dalam kampanye susah untuk dijerat.

\footnotetext{
${ }^{14}$ Gema Perdana, "Menjaga Netralitas ASN dari Politisasi Birokrasi", Negara Hukum, Vol. 10, No. 1 (2010), hal. 125

${ }^{15}$ Affan, MoU Bawaslu DIY, KPU DIY, dan KPID DIY, http://www.indofakta.com/news_13521.html, diakses pada 25 November 2019 pukul 11.20 Wib
} 
ASN tetap diharapkan mampu berlaku independen dan profesional dalam menjalankan fungsinya. Di samping itu ASN yang netral dan profesional merupakan prasyarat penting bagi terselenggaranya proses politik yang demokratis. ${ }^{16}$

\subsubsection{Kendala dari segi institusional}

Pelanggaran netralitas oleh ASN, TNI, Polri biasanya terjadi secara terstruktur, melibatkan struktur yang ada di pucuk pimpinan tetapi penindakan pelanggaran netralitas ASN sangat sulit, hal ini disebabkan karena tidak terpenuhinya minimal 2 (dua), alat bukti bukti dan saksi. Pelapor atau penemu biasanya hanya mendapatkan 1 (satu) alat bukti saja, misalnya dokumen, dan dokumen itupun kurang kuat untuk membuktikan tentang peristiwa pelanggaran yang terjadi atau tidak dapat membuktikan siapa pembuat dokumen tersebut.

\subsubsection{Kendala dari segi partisipasi masyarakat}

Masyarakat cenderung melakukan pembiaran jika ada pelanggaran netralitas ASN, perangkat desa, kepala desa, TNI atau Polri, hal ini disebabkan karena kekhawatiran/ ketakutan dari masyarakat atau karena adanya rasa sungkan jika harus melaporkan pelanggaran kepada pengawas pemilu sebab biasanya melibatkan pimpinan di instansi tersebut. Pengawasan terhadap proses pemilu di Indonesia telah dilembagakan dengan adanya Bawaslu. Disamping itu, terdapat juga pengawasan yang dilakukan oleh masyarakat terhadap proses penyelenggaraan pemilu yang disebut kegiatan pemantauan pemilu. ${ }^{17}$

\subsubsection{Sumber Daya Manusia (SDM) Bawaslu DIY terbatas}

Bawaslu DIY menghadapi kendala anggaran untuk mempersiapkan SDM dalam bidang penanganan pelanggaran, sehingga hanya ada beberapa kegiatan penyiapan SDM yang secara khusus membahas tentang penindakan pelanggaran, sebagai solusinya beberapa materi penguatan kapasitas dalam penindakan pelanggaran dan agenda penyamaan persepsi diikutkan dalam agenda penguatan kapasitas maupun rakor dalam bidang pengawasan.

Minimnya dana anggaran yang dimiliki Bawaslu DIY dan beberapa kali mengalami pemotongan anggaran dalam rangka efesiensi serta untuk mencukupi kekurangan anggaran untuk pembentukan Pengawas TPS yang belum terselenggara dengan baik. Hal tersebut menyebabkan beberapa pos anggaran Divisi Penindakan pelanggaran banyak yang direvisi atau bahkan dihilangkan dengan tujuan untuk mencukupi kekurangan anggaran tersebut. ${ }^{18}$

\footnotetext{
16 Mat Zudi, Arief Hidayat, Untung Sri Hardjanto, "Netralitas Pegawai Negeri Sipil dalam Pemilihan Kepala Daerah", Diponegoro Law Jurnal, Vol 1, No. 4, 2012

${ }^{17}$ Simanjuntak, N.Y, "Pemantauan dalam Proses Penyelenggaraan Pemilu", Jurnal Bawaslu, Vol. 3, No. 3, (2017), hlm. 307

${ }^{18}$ Hasil wawancara dengan Bapak Rachmat Hidayat Sofyan, Kepala Sub Bagian Hukum, Humas, dan Antar Lembaga Bawaslu DIY pada hari Senin tanggal 25 November 2019 pukul 09.30
} 


\section{Simpulan}

Bawaslu DIY melakukan pengawasan terhadap pelaksanaan pemilu dan pemilihan daerah berdasarkan Undang-Undang Nomor 7 Tahun 2017 dan juga merujuk pada peraturan Bawaslu Nomor 7 Tahun 2018. Pelaksanaan pengawasan meliputi upaya pencegahan dan penindakan pelanggaran pemilu termasuk pengawasan asas netralitas dari ASN di DIY yang menjadi fokus pengawasan Bawaslu DIY.

Upaya pencegahan pra pemilu yang dilakukan Bawaslu DIY untuk meredam potensi pelanggaran pemilu yaitu dengan pemetaan TPS dan menyusun Indeks Kerawanan Pemilu (IKP). Upaya lain yang dilakukan ASN adalah penerbitan surat himbauan terbuka maupun dialamatkan kepada instansi tertentu sebagai awal pencegahan pelanggaran pemilu, juga dengan melakukan MoU dengan berbagai instansi terkait dan kegiatan sosialisasi.

Sedangkan pada saat tahap pemilu dilangsungkan Bawaslu DIY secara langsung melakukan pengawasan dan monitoring pada setiap proses pemilu dapat melakukan tindakan pemprosesan atas pelanggaran yang dilaporkan oleh masyarakat ataupun memproses pelanggaran yang secara langsung ditemukan bawaslu dilapangan. Strategi selanjutnya dari Bawaslu DIY pada pasca pemilu yakni, melakukan investigasi dan penindakan segala macam pelanggaran pemilu yang terjadi berdasarkan regulasi yang sudah ada, kemudikan Bawaslu DIY secara intens melakukan cek dan follow up untuk memastikan bahwa pelanggaran-pelanggaran tersebut benar-benar diberikan sanksi hukum sesuai dengan peraturan perundang-undangan yang berlaku.

\section{Daftar Pustaka}

\section{Buku:}

Fajar, M., \& Achmad, Y. (2015). Dualisme Penelitian Hukum. Yogyakarta: Pustaka Pelajar.

Huda, N., \& Imam, N. (2017). Penataan Demokrasi \& Pemilu di Indonesia Pasca Reformasi. Jakarta: Kencana.

Kusnardi, M., \& Ibrahim, H. (1983). Hukum Tata Negara Indonesia. Jakarta: Pusat Studi Hukum Tata Negara FH UI.

Prasetyo, T. (2017). Pemilu Bermartabat. Depok: Rajawali Press

\section{Jurnal:}

Gema Perdana, "Menjaga Netralitas ASN dari Politisasi Birokrasi”, Negara Hukum, Volume 10, Nomor 1, Tahun 2010

Mat Zudi, Arief Hidayat, Untung Sri Hardjanto, "Netralitas Pegawai Negeri Sipil dalam Pemilihan Kepala Daerah”, Diponegoro Law Jurnal, Volume 1, Nomor 4, Tahun 2012 
Muhamad Jabar, Aji Ratna Kusuma, dan Adam Idris, "Strategi Pengawasan Bawaslu Pada Pemilihan Bupati/Walikota Serentak di Kalimantan Timur Tahun 2015”, eJournal Administrative Reform 2018, Volume 6, Nomor 1, Tahun 2018

Simanjuntak, N.Y, "Pemantauan dalam Proses Penyelenggaraan Pemilu", Jurnal Bawaslu, Volume 3, Nomor 3, Tahun 2017

Rahmatinnisa, "Mengapa Integritas Pemilu Penting?", Jurnal Bawaslu, Volume 3, Nomor 1, Tahun 2017

\section{Peraturan perundang-undangan:}

Undang-undang Dasar Negara Republik Indonesia Tahun 1945

Undang-Undang Nomor 15 Tahun 2011 tentang Penyelenggaraan Pemilihan Umum

Undang-Undang Nomor 5 Tahun 2014 tentang Aparatur Sipil Negara

Undang-Undang Nomor 7 Tahun 2017 tentang Pemilihan Umum

Peraturan Pemerintah Nomor 42 Tahun 2004 tentang Pembinaan Jiwa Korps dan Kode Etik Pegawai Negeri Sipil

Peraturan Pemerintah RI Nomor 53 Tahun 2010 tentang Disiplin Pegawai Negeri Sipil

Peraturan Komisi Pemilihan Umum Nomor 4 Tahun 2017 tentang Kampanye Pemilihan Gubernur dan Wakil, Bupati dan Wakil Bupati dan/atau Walokita dan Wakil Walikota Peraturan Bawaslu Nomor 21 Tahun 2018 tentang Pengawasan Pemilihan Umum

\section{Website:}

Affan, MoU Bawaslu DIY, KPU DIY, dan KPID DIY, http://www.indofakta.com/news_13521.html, diakses pada 25 November 2019 pukul 11.20 WIB

Bagus Sarwono, "Bawaslu Badan Pengawas Pemilu Daerah Istimewa Yogyakarta", https://docplayer.info/138498682-Bawaslu-badan-pengawas-pemilu-daerah-istimewayogyakarta.html, diakses 20 November 2019 pukul 15.30 WIB

\section{Hasil Wawancara:}

Rachmat, Hidayat. 2019. "Cara Meningkatkan Partisipasi Masayakarat dalam Pengawasan Pemilu". Hasil wawancara pribadi. Kantor Bawaslu DIY

Rachmat, Hidayat. 2019. "Proses Penjatuhan Sanksi kepada ASN". Hasil wawancara pribadi. Kantor Bawaslu DIY 
Media of Law and Sharia, Vol. 1, No. 4, 2020, 233-244

Sutrisnowati. 2019. "Peran Bawaslu saat Tahapan Pemilu". Hasil wawancara pribadi. Kantor Bawaslu DIY

Sutrisnowati. 2019. "Pelanggaran Regulasi ASN". Hasil wawancara pribadi. Kantor Bawaslu DIY 